\title{
Hydrodynamic impact on coal mass before crossing the most outburst-prone coal seams
}

\author{
Vasyl Vlasenko ${ }^{1, *}$, and Dmytro Zhytlonok ${ }^{2}$ \\ ${ }^{1}$ Institute of Geotechnical Mechanics named by N. Poljakov of National Academy of Sciences of \\ Ukraine, 49005, Dnipro, Simferopolska Str., 2a, Ukraine \\ ${ }^{2}$ State Enterprise "Toretskvuhillia", 85200, Toretsk, Druzhby Str., 19, Ukraine
}

\begin{abstract}
The results of experimental studies of hydrodynamic effects (HDI) in industrial conditions are given. The HDI is designed to reduce the gas-dynamic activity of the coal seam and the rocks surrounding it. HDI was applied to the coal seam before it crossed the mine workings. The conditions for the implementation of HDI in industrial conditions Separate Enterprise "Mine "Tsentralna" State Enterprise "Toretskvuhillia" are described. The results of HDI on coal seams $m_{2}$ - "Tonkyi" and $m_{3}$ "Tovstyi" are given. The parameters of the HDI method for outburst-prone coal seam before its crossing by mine workings are corrected.
\end{abstract}

\section{Introduction}

The prevention of the manifestation of gas-dynamic phenomena (GDP) in coal mines is given special attention and a number of methods have been developed. A special place is adopted by the processes of impact on the coal seam, which help prevent GDP by changing the state of the coal seam [1]. These methods include HDI.

The high efficiency of the HDI method is confirmed by the successful long-term practice of using it for the degassing of coal seams and getting them to a outburst-prone state. [2]. This makes HDI one of the most promising direction in the management of the mountain massif state with the purpose of its degassing and reduction of gas-dynamic activity. The forces of rock and gas pressure are used more fully as active forces, and the vibrational properties of system "the coal seam - enclosing rocks" are activated with this action method. [3, 4].

The HDI method involves drilling a technological well onto a coal seam through a fivemeter rock bridge. As a result of the impact, is coal softening, its moistening and degassing of the seam, which prevents the manifestation of signs of GDP.

The aim of the work is adjusting the parameters of the HDI method through one underground well to coal seams that are prone to GDP before completion them in the conditions SE "Mine "Tsentralna” SE "Toretskvuhillia".

Research objectives:

- identify elements of the HDI technology, the adjustment of which will lead to an increasing in the efficiency of processing the coal seam;

\footnotetext{
"Corresponding author: VVVlasenko@nas.gov.ua
} 
- perform a series of industrial tests of the HDI method before completion the coal seams with a sectional tunnel;

- analyze of mine instrumental measurements;

- based on the findings to implement the parameters correcting of the HDI method.

The object of the research is the processes occurring in a strained gas-saturated coal and rock massif at HDI on it, through a well drilled from the bottom of the intermediate crosslayer through the rocks of the soil to the coal seam.

\section{Methods}

Explore operations of the HDI method for outburst-prone coal seams before completion them through one well was performed in an industrial environment. The operations were carried out in accordance with the "Methodology of acceptance (industrial) method testing of opening coal seams prone to GDP using hydrodynamic effects with crossdrift" [2].

Industrial trial of method performed on the coal seams $m_{2}$ - "Tonkyi" and $m_{3^{-}}$"Tovstyi" in the conditions SE "Mine "Tsentralna" SE "Toretskvuhillia".

\subsection{Equipment for performance HDI}

Equipment for HDI (Fig. 1) on the seam is comprised of pumping station, hydrodynamic impact device (HID) [5], control panel and high-pressure hoses. Pumping station powered by pneumatic engine. The hydrodynamic impact device is comprised of connected spring mechanism of a hydraulic cylinder and a high pressure valve. High pressure gate valve (HPDV200/4) with a flow area of $96 \mathrm{~mm}$ in diameter, operating pressure up to $30 \mathrm{MPa}$. The hydraulic cylinder is designed for a pressure of $20 \mathrm{MPa}$. The remote controller consists of an oil pump driven by hydraulic cylinder and pressure gauges. The remote controller is connected to the hydraulic cylinder with high-pressure hoses [6].

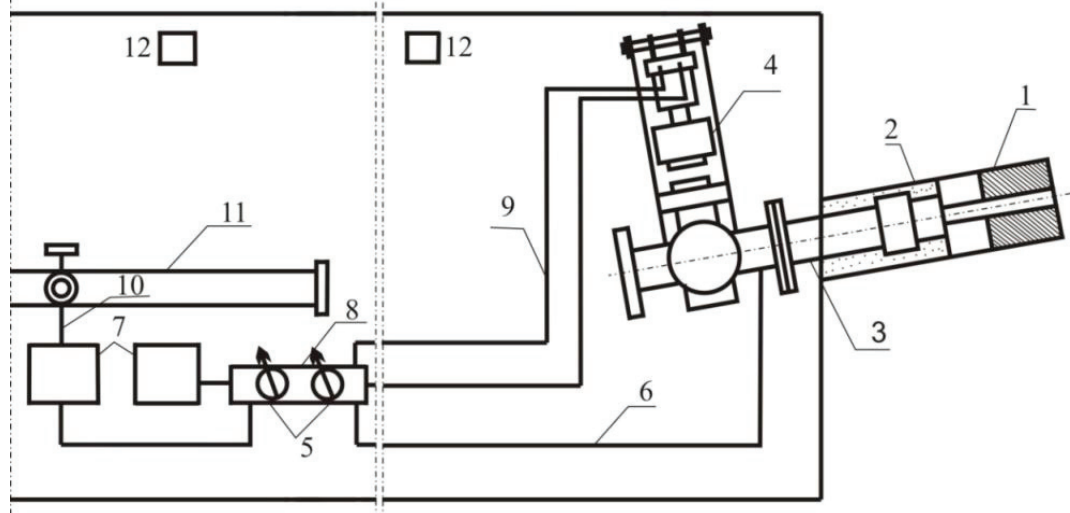

Fig. 1. The layout of equipment HID in the working: 1 - coal well; 2 - rock well; 3 - core-shell; 4 HID; 5 - pressure gauge; 6 - high pressure hoses for water supply; 7 - pumps; 8 - HID control panel; 9 - high pressure hoses for controlling the HID; 10 - pump supply hose; 11 - fire protection; 12 - sensor gas control equipment.

\subsection{Site preparation}

HDI to the coal seam was performed through a well drilled through the rocks of the seam soil. The wells were drilled from the bottom of the intermediate crossdrift of the III eastern and III western fringedrift on the horizon of $1146 \mathrm{~m}$ (Fig. 2). Cross-section of the crossdrift 
in the drifting $S_{d r}=12.3 \mathrm{~m}^{2}$.
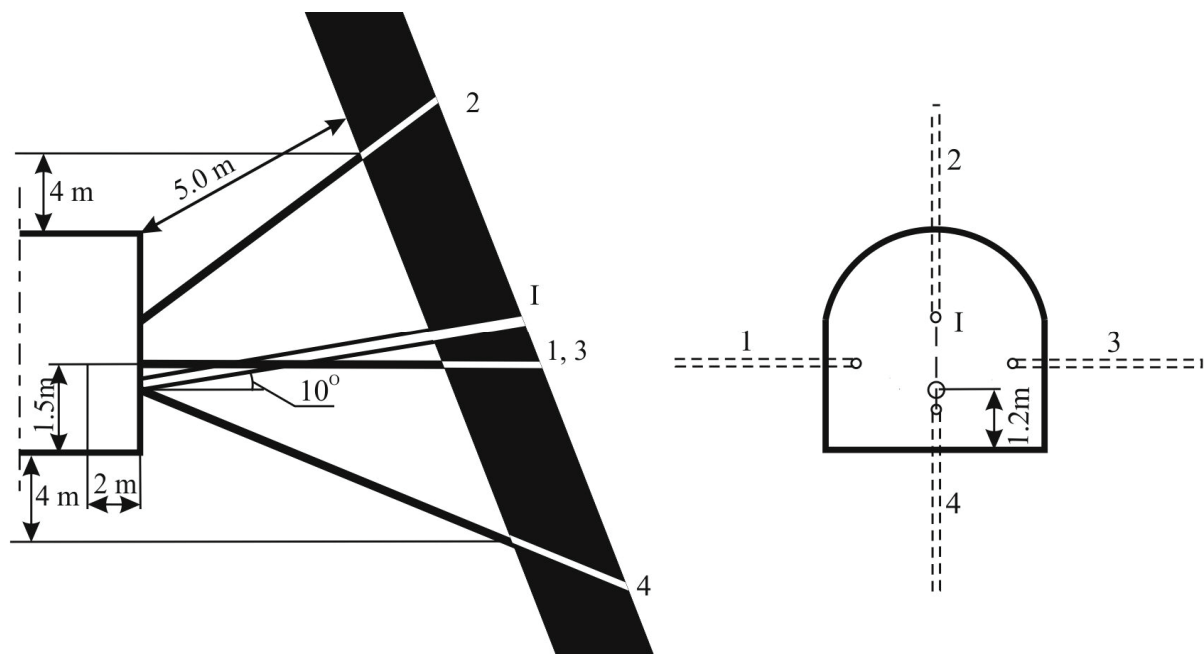

Fig. 2. The layout of the technological and measuring wells: 1-4 - control wells, I - technological well.

To conduct HDI [2], one technological and four control wells were drilled for the seam. The pressure gauge were installed at the control wells to monitor the reservoir gas pressure.

The technological well was drilled in two stages: drilling a well with a diameter up to $80 \mathrm{~mm}$ to the designed length; underreaming of the well rock part to a diameter of 150 $190 \mathrm{~mm}$.

Technological well surrounded by metal pipes. Diameter of pipes is from 105 to 115 $\mathrm{mm}$. The well was planted on the thickness of the rock plug. The tubular space was filled with sand-cement mortar using compressed air.

The length of the protuberance part in working of the pipe with the mounting flange was 0.5-0.7 m. After immobilization of the mortar on the mounting flange of the core-shell was installed HID and performed the installation of the necessary equipment.

Installation of equipment and its adjustment was carried out during one shift.

\section{Results and discussion}

\subsection{Characteristics of coal seams $m_{3}$ - "Tovstyi" and $m_{2}$ - "Tonkyi"}

Under the conditions of a mine field, the coal seam $m_{3}$ - "Tovstyi" has a thickness of: geological - 1.42-1.90 m; working - 1.30-1.65 m; removable - 1.72-2.20 m. The incidence angle of the seam and rocks $55-62^{\circ}$. Coal seam throughout the panel mine section sustained in thickness and structure. The structure of the seam is complex. The seam coal is brittle, the fracture is uneven, the coal is easily exfoliated, coked, grade $G$ type of coal disturbance II. Natural gas content $18-20 \mathrm{~m}^{3} / \mathrm{t}$ d.a.r.m. ( $\mathrm{m}^{3} / \mathrm{t}$ of dry ash-free rock mass) volatile-matter yield $29.0-32.2 \%$. With the removal to the west, the gas-dynamic activity of the seam decrease, coal hardness on-scale of prof. Protodyakonova 1.0-1.2, unit weight $1.32 \mathrm{t} / \mathrm{m}^{3}$.

The seam is dangerous due to coal and gas outburst, coal fall, coal dust explosibility, not given to fire breeding, not dangerous to rock burst shock. Workings, traversed by the seam $m_{3}$ are not dangerous for the breakthrough of methane from the soil.

There are no faultings in the field of the extraction district. Zones with unstable lateral rocks can occur. 
Depth of operations - 1026-1146 m.

Coal seam $m_{2}$ - "Tonkyi", is dangerous due to coal and gas outburst, coal fall, coal dust explosibility. The seam of complex structure, the total normal thickness $1.1 \mathrm{~m}$ and the angle of incidence $62^{\circ}$.

Seam structure:

- coal slate, loose, incompetent, with coal and argillaceous shale seam, thickness layer $0.53 \mathrm{~m}$;

- argillaceous shale lenticular structure alternate with coal and carbon-bearing shale, incompetent, thickness $0.25 \mathrm{~m}$;

- semilustrous coal, subaverage strength, alternate with coal shale, thickness $0.32 \mathrm{~m}$, type of coal fracturing II-III.

Natural gas content $-19 \mathrm{~m}^{3} / \mathrm{t}$ d.a.r.m.)

Coal seam $m_{2}-$ "Tonkyi" are not practiced currently.

\subsection{Points of order HDI}

HDI on coal seam is performed after hardening of the grouting mortar.

Water is injected with pumping station from at technological well through the HID. Injection is carried out in the filtration mode $-30-401 / \mathrm{min}$.

For this process in the well water was supplied from the mine fire part in the filtration mode at a rate $30-40 \mathrm{l} / \mathrm{min}$. When reaching pressure at the well 2-7 MPa carried out a sudden depressurization by opening the wedge gate HID.

The feed and discharge cycles of the fluid are repeated until the extraction from the technologycal well estimated amount of the destroyed coal. The radius of the treatment area of the lower part of the band was determined by the formula [2]:

$$
R_{0}=\sqrt{\frac{M_{c}}{2 \cdot 10^{-3} \pi m \gamma}}, \quad \mathrm{m},
$$

where $M_{c}$ - mass of coal yield from labored zone, $\mathrm{t} ; m$ - depth of seam, $\mathrm{m} ; \gamma$ - coal unit weight, $\mathrm{t} / \mathrm{m}^{3}$.

All parameters of the impact process are recorded with devices installed at the remote operating panel.

\subsection{Results HDI}

To adjust the method parameters of six coal seams were processed in conditions SE "Mine "Tsentralna" SE "Toretskvuhillia".

HDI on coal seam $m_{2}$ - "Tonkyi" from mine face manufacturing crossdrift \#27 site \#41-1146 m operate during $4 \mathrm{hr} 14 \mathrm{~min} 25$ cycles of exposure were performed. A pressure of up to $7 \mathrm{MPa}$ was created, but the process of extracting coal and gas through the well did not start. To implement HDI in full was failed. During the entire implement process, the reservoir gas pressure was zero. Measurement of reservoir gas pressure was performed by gauges in control wells (Fig. 1).

Further formation processing has been performed in the water injection into the formation mode according to the [7].

HDI on coal seam $m_{3}$ - "Tovstyi" from mine face manufacturing crossdrift \#27 site \#41$1146 \mathrm{~m}$ operate during $177 \mathrm{~min}$. 22 cycles of exposure were performed. The maximum injection pressure was 5.0 MPa. In the process injection through the well extracted $12.0 \mathrm{t}$ of coal. This indicates a treated area with a radius $12.4 \mathrm{~m}$. During the impact, the concentration of methane in the bottom of the intermediate manufacturing crossdrift did not 
exceed $2 \%$. The coal seam was degassed in the area $333 \mathrm{~m}^{2}$. Seam drilling in $m_{3}-$ "Tovstyi" in manufacturing crossdrift \#27 carried out without signs of gas-dynamic phenomena.

The following four HDI are similar. In the process of which the estimated amount of coal was extracted from wells. The HDI results for outburst coal seams are shown in Table 1.

Table 1. Results of hydrodynamic impact.

\begin{tabular}{|c|c|c|c|c|c|c|c|}
\hline Seam & Site & 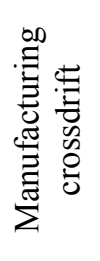 & 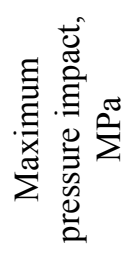 & $\begin{array}{l}\stackrel{\tilde{g}}{\Xi} \\
\stackrel{\Xi}{\tilde{\tilde{E}}} \\
\stackrel{\Xi}{\Xi}\end{array}$ & 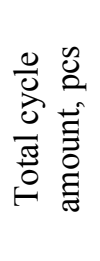 & 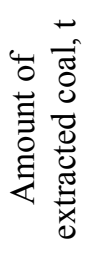 & 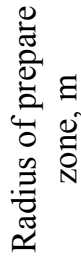 \\
\hline$m_{2^{-}}$"Tonkyi" & \multirow{2}{*}{$41-1146$} & \multirow{2}{*}{ \#27 } & 7.0 & 254 & 25 & - & - \\
\hline$m_{3}$ - "Tovstyi" & & & 5.0 & 177 & 22 & 12.0 & 12.4 \\
\hline$m_{2^{-}}$"Tonkyi" & \multirow{4}{*}{$42-1146$} & \multirow{2}{*}{$\# 12$} & 3.0 & 237 & 14 & 8.0 & 9.2 \\
\hline$m_{3}$ - "Tovstyi" & & & 4.0 & 236 & 28 & 10 & 16.9 \\
\hline$m_{2^{-}}$"Tonkyi" & & \multirow{2}{*}{$\# 13$} & 3.0 & 184 & 20 & 10.0 & 10.3 \\
\hline$m_{3}$ - "Tovstyi" & & & 7.0 & 323 & 32 & 4.5 & 4.1 \\
\hline
\end{tabular}

At the completion of gas-saturated coal seams $m_{2^{-}}$"Tonkyi" and $m_{3}$ - "Tovstyi" there were no signs of gas-dynamic phenomena. Monitoring of the effectiveness taken measures was carried out to extract the estimated amount of coal.

The practical value consists in the fact that the completion of six outburst-prone seams took place without signs of gas-dynamic phenomena, there were no interruptions of work on the gas factor when approaching the coal seam and moving away from it.

\section{Conclusions}

1. It has been established that HDI through one well with a diameter $100 \mathrm{~mm}$, drilled through the rock plug of soil layers with a thinness of more than $5 \mathrm{~m}$ along the normal from the working face of the completion production section in the excavating of up to $12.3 \mathrm{~m}^{2}$ to the coal seam, in an amount from 14 to 32 cycles the treatment of at least $2 \%$ of coal causes the coal seam in a outburst-prone state on a site with a radius of 4.1-16.9 m.

2. As a result of industrial testing of the method, the HDI parameters for the coal seam were corrected:

- number of the technologies wells, pcs

1

- impact process pressure, $\mathrm{MPa}$

$3-7$;

- number of cycles, pcs

$14-32$.

\section{References}

1. Guselnikov, L.M., Osipov, A.N., Ganshevskiy, S.P. (2000). Sovershenstvovaniye sposobov aktivizatsii gazovydeleniya pri degazatsii nerazgruzhennykh ugolnykh plastov. GIAB, 2, 93-95

2. Sofiyskiy, K.K., Gavrilov, V.I., Zhitlenok, D.M., Vlasenko, V.V., Petukh, A.P. (2015). Gidrodinamicheskiye sposoby vozdeystviya na napryazhennyye gazonasyshchennyye ugolnyye plasty. Donetsk: Skhidnyi vydavnychyi dim

3. Sofiyskiy, K.K., Baradulin, V.G., Aleksandrov, V.G. (1998). Sposob dobychi metana iz 
ugolnykh plastov. Dnepropetrovsk: DGA, (5), 128-131

4. Churadze, M.V. (2000). Sposoby gidravlicheskogo vozdeystviya na ugolnyye plasty dlya borby s vnezapnymi vybrosami uglya i gaza. GIAB, 7, 219-222

5. Amelin, V.A., Baradulin, Ye.H., Demidov, I.P., Nechytailo, V.O., Portianko, V.P., Sylin, D.P., Sofiiskyi, K.K., Shmelov, M.O. (1997). Prystrii dlia hidrodynamichnoi dii na vuhilnyi plast. Patent No. 19956, Ukraine

6. V. Vlasenko, R. Agaiev, K. Dudlia, M. Kyrychenko, D. Prytula, On the Possibility of Coalbed Methane Extraction as a Source of Energy under the Hydrodynamic Impact on the Outburst Coal Seam. Advanced Engineering Forum Submitted, Switzerland: Trans Tech Publications, 25 (2017)

7. Ukraine Ministry of Coal Industry (2005), 10.1.00174088.011:2005. Pravyla vedennia hirnychykh robit na plastakh, skhylnykh do hazodynamichnykh yavyshch. Kyiv, Ukraine 